УДК 343.85

DOI https://doi.org/10.32849/2663-5313/2021.2.41

\title{
Андрій Кротюк,
}

канд. юрид.наук,

доцент кафедри кримінології та кримінально-виконавчого права

Національної академії внутрішніх справ

\section{ЗАГАЛЬНОСОЦІАЛЬНІ ЗАХОДИ ЗАПОБІГАННЯ ЗЛОЧИНАМ У СФЕРІ НЕЗАКОННОГО ОБІГУ НАРКОТИЧНИХ ЗАСОБІВ, ПСИХОТРОПНИХ РЕЧОВИН, ÏХ АНАЛОГІВ I ПРЕКУРСОРІВ У ВЕЛИКОМУ МІСТІ}

Проблема запобігання злочинам у сфері незаконного обігу наркотичних засобів, психотропних речовин, їх аналогів і прекурсорів у великому місті повинна вирішуватися в руслі протидії злочинності взагалі. Обов'язковою передумовою успіху в реалізачії загальносочіальних заходів запобігання злочинам у сфері незаконного обігу наркотичних засобів, психотропних речовин, їх аналогів і прекурсорів $і$ всій злочинності взагалі є досягнення якісно іншого стану нашого суспільства, в якому людина повинна мати міцний життєвий статус. Для цього необхідно зробити істотні перетворення у найважливіших сферах суспільного життя з урахуванням при ивому інтересів усіх верств суспільства. Для запобігання злочинам у сфері незаконного обігу наркотичних засобів, психотропних речовин, їх аналогів і прекурсорів необхідно реалізувати комплекс сочіально-економічних, політичних, організачійно-управлінських, виховних, технічних, правових та інших заходів. Запобігання вчиненню злочинів, здійснюване підрозділами НП України у великих містах, - ие складний, багатогранний процес, що має певні ознаки иілісності. Тому його доиільно розллядати комплексно, виділяючи складові елементи. Загальносочіальне запобігання злочинам у сфері незаконного наркообігу визначається трьома найважливішими складниками, які породжують саме ией вид антисочіальної поведінки, - економічним, сочіальним і моральним. Виходячи з ивого, існує три сфери, в яких необхідно передусім здійснювати запобіжну роботу на загальносочіальному рівні: економічна, сочіальна і морально-психологічна. Відповідно, у статті проаналізовано та запропоновано загальносоціальні заходи запобігання злочинам у сфері незаконного обігу наркотичних засобів, психотропних речовин, ïх аналогів і прекурсорів у великому місті.

Ключові слова: запобігання, загальносоціальні заходи, організовані злочинні групи, наркотичні засоби, наркотичні засоби, велике місто.

Постановка проблеми. Нині гостро постало питання боротьби з наркоманією. У великих містах наркотики, здебільшого хімічні, легко купити через мережу Інтернет чи месенджер «Телеграм». Оплата при цьому відбувається через платіжні термінали. У молоді формується нове поняття «закладки» - схованки (тайники) з наркотичною речовиною. Для багатьох пошук наркотичних засобів починається 3 гри в «Квест» - пошук схованки з наркотиками, який підвищує рівень адреналіну і викликає певне задоволення [1].

Проблема запобігання вчиненню злочинів взагалі завжди була актуальною для кримінологічного дослідження. 3 цього приводу цікавою є думка Монтеск'є, який у своїх дослідженнях наголошував, що «гар- ний законодавець не стільки піклується про покарання за злочини, скільки про запобігання злочинам. Він також прагне не стільки карати, скільки покращувати нрави» [2, c. 123].

Правовими засадами діяльності підрозділів НП України щодо запобігання вчиненню злочинів у сфері незаконного обігу наркотичних засобів, психотропних речовин, їх аналогів і прекурсорів у великому місті є законодавчі та галузеві нормативно-правові акти, що комплексно регулюють статус, завдання, функції, повноваження, обов'язки і права працівників НП України, для яких запобігання злочинності є одним із головних завдань.

Запобігання вчиненню злочинів, здійснюване підрозділами НП України, у великих містах - це складний, багатогранний 
процес, що володіє певними ознаками цілісності. Тому його доцільно розглядати комплексно, виділяючи складові елементи. Залежно від масштабу застосування заходи запобігання, на думку А.I. Дольової, можуть бути: загальнодержавні; такі, що стосуються великих соціальних груп; такі, що стосуються окремих об’єктів або мікрогруп; індивідуальні заходи [3, с. 272]. Крім того, за змістом заходи запобігання злочинності вона поділяє на економічні, політичні, соціальні, культурно-виховні, правові та інші.

Отже, запобігання злочинності як розділ кримінології являє собою, так би мовити, їï квінтесенцію, те, для чого кримінологічні дослідження викликаються до життя. Без теорії і практики запобігання злочинності весь масив кримінологічних знань залишався би простим набором фактів та узагальнень, що не мав би прикладного, соціально корисного характеру. Синтез цих знань та формулювання на його основі конкретних заходів щодо запобігання злочинності виводять будь-яке кримінологічне дослідження на справжній науковий рівень, не дозволяють кримінології відриватись від об'єктивної реальності, а навпаки, роблять будь-яке кримінологічне дослідження необхідною умовою прийняття рішень в рамках проведення кримінально-правової політики [4, с. 139].

Відповідно, у цьому дослідженні охарактеризуємо загальносоціальні заходи запобігання корисливим насильницьким злочинам, що вчиняють етнічні організовані злочинні групи. Так, під час анкетування органів Національної поліції України 78 \% відзначили, що вважають заходи масового впливу найбільш результативними заходами під час запобігання злочинам у сфері незаконного обігу наркотичних засобів, психотропних речовин, їх аналогів і прекурсорів у великому місті, що зумовило вибір теми наукової розвідки.

Метою статті $є$ визначення основних напрямів загальносоціальних заходів запобігання злочинам у сфері незаконного обігу наркотичних засобів, психотропних речовин, їх аналогів і прекурсорів у великому місті та розробка системи таких заходів.

Виклад основного матеріалу. На загальному рівні профілактику спрямовано на обмеження дії негативних явищ і процесів, пов'язаних зі злочинністю; усунення (нейтралізацію) детермінантів злочинних проявів; ліквідацію криміногенних факторів у мікросередовищі особи, які формують іï антигромадську позицію і мотивацію злочинної поведінки.

Загальне запобігання злочинам у великому місті - це комплекс практичних захо- дів підрозділів карного розшуку, спрямованих на усунення або нейтралізацію причин та умов злочинності [5, с. 88].

У цілому їх також можна визначити як заходи, спрямовані на підвищення добробуту та культурного рівня населення, укріплення правопорядку. До загальних заходів запобігання злочинності у великому місті слід віднести:

- розвиток і вдосконалення економічних відносин, технологічних процесів і технічного оснащення виробництва - промислового, сільськогосподарського, що нерозривно пов'язане $з$ підвищенням життєвого рівня і матеріального добробуту людей;

- підвищення рівня культури членів суспільства, поліпшення їхньої освіти, а отже, вихованості, встановлення етичних поглядів, заснованих на всьому тому кращому, що накопичило людство в цій сфері за весь період свого розвитку тощо [6, с. 149].

Отже, причиною вчинення конкретного злочину вважають ті негативні явища і процеси, під впливом яких у винної особи виник комплекс сваволі та ілюзій. Умовою - ті явища і процеси, в результаті яких цей комплекс проявився у вигляді злочину [7, с. 236].

Кримінологія як наука, досліджуючи ці загальносоціальні процеси (їх негативний вираз), рекомендує, як слід було б вчинити в тих або інших ситуаціях. Такі рекомендації тоді ефективні, коли даються з урахуванням реальних можливостей суспільства (економічних, фінансових і т. д.), а не абстрактно теоретично. Водночас кримінологія гостріше бачить негативний вплив на життя суспільства тих або інших, скажімо, економічних експериментів (чого, на жаль, не хочуть визнавати багато економістів і політиків). Тому ïï рекомендації далеко не відразу сприймаються, тим більше реалізуються.

Проблема запобігання злочинам у сфері незаконного обігу наркотичних засобів, психотропних речовин, їх аналогів і прекурсорів у великому місті повинна вирішуватися в руслі протидії злочинності взагалі. Обов'язковою передумовою успіху в реалізації загальносоціальних заходів запобігання злочинам у сфері незаконного обігу наркотичних засобів, психотропних речовин, їх аналогів і прекурсорів і всій злочинності взагалі є досягнення якісно іншого стану нашого суспільства, в якому людина повинна мати міцний життєвий статус. Для цього необхідно зробити істотні перетворення у найважливіших сферах суспільного життя 3 урахуванням при цьому інтересів усіх верств суспільства. Для запобігання злочинам у сфері незаконного обігу наркотичних засобів, психотропних речовин, їх аналогів 
і прекурсорів необхідно реалізувати комплекс соціально-економічних, політичних, організаційно-управлінських, виховних, технічних, правових та інших заходів. Загальносоціальне запобігання злочинам у сфері незаконного наркообігу визначається трьома найважливішими складниками, які породжують саме цей вид антисоціальної поведінки: економічним, соціальним і моральним. Виходячи 3 цього, існує три сфери, в яких необхідно передусім здійснювати запобіжну роботу на загальносоціальному рівні: економічна, соціальна і морально-психологічна

В економічній галузі першим і головним напрямом запобігання злочинності є подолання безробіття. Згідно з даними американських фахівців між рівнем безробіття і кількістю засуджених до позбавлення волі існуе практично пряма залежність [8]. Проведене нами дослідження свідчить, що близько 78 \% злочинців у сфері незаконного наркообігу є безробітними, багато тих, хто втратив роботу внаслідок скорочення робочих місць. А можливість здобути злочинним шляхом доходи, які чесною працею заробити не можна, штовхає людей займатися злочинами у сфері незаконного обігу наркотичних засобів, психотропних речовин, їх аналогів і прекурсорів у великому місті. Така проблема відсутня у сільських мешканців, які займаються культивуванням снотворного маку, що приносить значний дохід. Тому дієвою перешкодою на шляху злочинності повинно стати максимальне відновлення робочих місць, вчасна виплата заробітної плати, пенсій, інших видів соціальної допомоги, надання робочих місць молоді. Злочинному «заробітку» необхідно протиставити легальні можливості працювати. Крім цього, безробіття пов'язане з таким соціальним явищем, як вимушена міграція населення. Більшість мігрантів - люди молодого віку. 3 відривом від постійного місця проживання в пошуках роботи на новому місці часто втрачаються зв'язки з рідними і близькими, знижується ефективність впливу сім'ї на поведінку і духовний світ людини, тобто «знімається» важлива форма соціального контролю, що не завжди позитивно позначається на житті людини. Молоді люди - мігранти, які не мають достатнього життєвого досвіду, стійких поглядів і переконань, часом не можуть протистояти негативним впливам і знайти вихід зі складної життєвої ситуації в період адаптації на новому місці [9, с. 134]. 3 метою подолання цих негативних явищ необхідно на загальнодержавному i регіональному рівнях вжити заходів, спрямованих на вдосконалення управління процесами міграції, надання їм організованих форм, зменшення фактів бродяжництва, що можна зробити в межах розробки і впровадження спеціальних програм. Над цими документами повинні працювати фахівці та має бути передбачене достатне фінансування, визначені пріоритетні завдання і напрями роботи.

Особливої турботи держави вимагає соціальна сфера, насамперед сім'я. Криміногенні нахили особистості злочинця у сфері незаконного наркообігу здебільшого пов'язані 3 недоліками сімейно-побутових відносин, прорахунками у виховній роботі, матеріальною незабезпеченістю сім'ї батьків і власної родини. Проблема наркотиків може торкнутися як багатих, так і бідних сімей, різниця лише в тому, що діти з багатих родин вживають дорогі наркотики, а діти з бідних родин - дешевші. Проведене нами дослідження свідчить, що 40 \% злочинців відзначили, що зростали у неблагополучних сім'ях. Зростаючи на грунті негативних явищ у сім'ї і найближчому соціальному оточенні, наркоманія ніби відтворює і ще більше загострює їх, призводячи до практично повної дестабілізації сім'ю і шлюб, а тим самим і нормальне відтворення населення і соціалізацію особистості. Існує очевидний зв'язок між фізичним, психологічним, сексуальним насильством над дітьми, поганим ставленням до них і наявністю в сім'ї наркологічних хворих. У таких сім'ях у дітей підвищений ризик захворювань, порушень розвитку і соціальної адаптації. У цій сфері роботу необхідно вести у декількох напрямах одночасно.

Перший напрям - це виховна робота 3 підростаючим поколінням, допомога батькам у вихованні дітей. Батьки через зайнятість приділяють недостатню увагу вихованню дітей. Тут основний тягар лягає на школу. Але шкільний вчитель надто перевантажений викладацькою роботою, щоб на додаток до неї займатися ще позакласною виховною роботою. Тому доцільно в середніх школах, професійних училищах запровадити штатну одиницю педагогів-вихователів, звільнених від навчальних занять. Такі педагоги потрібні, починаючи з молодших класів. Звільнений від навчального навантаження педагог-вихователь міг би вивчати життя підлітків, займатися з ними у вільний від занять у школі час, формувати і впливати на їхні інтереси, умови життя, надавати допомогу батькам у вихованні дітей. У зв'язку 3 цим необхідно належну увагу приділяти підготовці в середніх спеціальних і вищих навчальних закладах кадрів за спеціальністю педагог-вихователь.

Другий напрям - захист інтересів незаможних громадян, у тому числі матеріальна та інша допомога малозабезпеченим сім'ям, 
оскільки саме матеріальна незабезпеченість $€$ тим фактором, який спричиняє вибір людиною злочинного шляху. Проведене нами дослідження свідчить, що більша частина сімей мали низький матеріальний достаток або ж взагалі не мали засобів до існування.

Третій напрям - зважена політика у сфері планування сім'ї і зміцнення сімейних засад. Багатьом сім'ям абсолютно незнайомі, а якщо знайомі, то недоступні, програми планування сім'ї. А, як відомо, багатодітність - не завжди благо в непростих економічних умовах сьогодення. Центри планування сім'ї повинні бути доступні всім бажаючим. Крім того, потрібна служба сім'ї, де можна було б отримувати консультації і допомогу з широкого кола питань, наприклад психотерапевтичну допомогу особам, у кого в сім'ях є наркомани. Необхідно взяти на озброєння також консолідацію сімей за громадським (національним) принципом, наприклад, шляхом проведення сімейних общинних свят, створення недільних шкіл.

Четвертий напрям - боротьба з алкоголізмом, корекція психічних захворювань. Це дуже важкий напрям роботи, який вимагає великих зусиль і витрат. Передусім необхідне створення розгалуженої державної мережі лікувальних установ даного профілю; здійснення, аж до примусового, своєчасного лікування осіб, що страждають на цей недуг, прийняття спеціальних державних програм боротьби з наркоманією, пияцтвом, алкоголізмом. Крім того, заборонити у громадських місцях і в засобах масової інформації рекламу тютюнових і алкогольних виробів, розгорнути могутню антирекламу, роз'яснювальну роботу серед населення. Доцільно передбачити і спрощений порядок обмеження дієздатності алкоголіків і наркоманів.

Важливу роль у справі оздоровлення і вдосконалення суспільних відносин відіграють різні програми (плани) економічного і соціального розвитку, що приймаються як на загальнодержавному, так і на регіональному рівнях $[10 ; 11 ; 12 ; 13]$. У цих програмах передбачається широкий спектр заходів, спрямованих на забезпечення гарантованих Конституцією України прав громадян, у тому числі на працю, відпочинок, здобуття освіти та професійної підготовки і перепідготовки, охорону здоров'я, материнства і дитинства, підтримку соціально незахищених верств населення з боку держави, гідний рівень життя для себе і своєї сім'ї, запобігання масовому безробіттю і забезпечення повної зайнятості населення. Безперечно, це необхідні програми. Однак проблема полягає в тому, що заходи фінансуються, як правило, не в повному обсязі або навіть за залишковим принципом. Це підтверджено й опитуванням респондентів у $89 \%$.

У політичній сфері антикриміногенний потенціал несуть заходи, спрямовані на утвердження істинно демократичних принципів побудови національної державності. Довгий час під закликами до безмежної демократії впроваджувалася практика виведення керівників державних органів, регіональних і галузевих органів влади і управління з-під відповідальності перед виборцями, широкою громадськістю. Вважаємо, що в цій сфері антикримінальними заходами є: багатопартійність, продуманий механізм розподілу влади в державі, звітність відповідальних посадових осіб перед народом, декларування прибутків осіб, які посідають ключові пости в державі, прийняття найважливіших державних програм економічного і соціального розвитку 3 урахуванням думки громадян України, проведення зваженої політики у вирішенні національних питань тощо.

На тлі кризи соціальної сфери має місце втрата соціальних орієнтирів. Соціалістична система цінностей, що існувала протягом багатьох десятиліть, самоліквідувалася, а нова й досі не сформувалася. Держава, церква, інші суспільні інститути мають украй незначний вплив на формування системи суспільних поглядів основної частини населення. Особливо це стосується неповнолітніх та молоді. Опинившись без уваги держави та суспільства, вони відчувають себе «зайвими людьми», «втраченим поколінням». Тому наркоманія у великих містах України сприймається багатьма 3 них як спосіб «суспільного самогубства», відхід від суспільства, яке їх не потребує і для якого вони є зайвими, незатребуваними.

Держава і суспільство в цілому зобов'язані негайно повернутися до проблем зайнятості молоді. 3 цією метою необхідно розробити і прийняти реальну державну програму зайнятості або соціальної влаштованості, забезпечення молоді. Зрозуміло, що для цього потрібні кошти. Тому держава повинна вирішити, що важливіше: економія коштів i ïx вкладання в інші програми, не завжди повною мірою продумані і виправдані, чи здоров'я, майбутнє нації [14, с. 6-9].

Необхідно також із максимально ефективно використовувати всі наявні палаци культури, клуби, бібліотеки, концертні зали, стадіони для розгортання виховної, культурно-масової роботи, а також створювати нові такі заклади. У державних та місцевих бюджетах великих міст для вказаних потреб необхідно виділяти достатнє асигнування. Потрібно залучати для створення центрів організованого дозвілля населення 
комерційні структури, різні добродійні організації, фонди, громадські об'єднання. У зв'язку з цим не слід відкидати досвід радянського часу, коли по всій країні працювали Палаци піонерів, різні гуртки, клуби за інтересами. Їхнє антикриміногенне значення було очевидним, оскільки вони організовували і наповнювали змістом стихійне вуличне дозвілля дітей та підлітків, допомагали знайти друзів за інтересами, забезпечували вибір занять, у тому числі і для осіб із невисоким культурним рівнем, значно полегшували соціальний контроль за їхньою поведінкою. Вакуум, що утворився зараз, заповнили різні релігійні секти, угруповання сатаністів, екстремістські націоналістичні групи тощо Нагальною є необхідність відродження позитивного досвіду організації дозвілля підростаючого покоління. Профілактичне значення має також розширення мережі дитячих, спортивних і трудових таборів.

Демонстративно зневажливому ставленню дозагальноприйнятих норм поведінки, культивуванню сили, наживи, лихослів'я насильства потрібно протиставляти здоровий спосіб життя, справжню справедливість, а не самосуд, так звану «справедливу» розправу. 3 урахуванням цього повинні бути розставленні правильні акценти в роботі 3 морального формування підростаючого покоління. Вміло організована пропаганда спроможна забезпечити активне розвінчання антисуспільних норм, звичок, традицій, «героїв» злочинного світу і націлювати людину на справжні ціннісні норми. При цьому особливу роль у морально-психологічному формуванні людини повинна відігравати культурна спадщина нації. Загалом піднесення культурного рівня народу є важливим внеском у вирішення завдання обмеження злочинності.

Загальносоціальний напрям у запобіганні злочинності діє і в правовій сфері суспільних відносин. Правова сфера боротьби зі злочинністю представлена декількома основними аспектами діяльності. Один із них - вдосконалення законодавства, яке хоча прямо і не націлене на запобігання злочинності, однак має своїм завданням правове врегулювання інших суспільних відносин.

Ще один аспект - наукові фундаментальні та прикладні розробки в галузі проти дії злочинності. Загальносоціальні заходи в правовій сфері є особливо важливими для запобігання злочинам у сфері незаконного наркообігу, оскільки особи, які мають намір, припустимо, на збут наркотичних засобів, повинні знати, наскільки суворими будуть для них кримінально-правові наслідки у разі скоєння даного злочину. Ще непоодинокими
$€$ випадки, коли злочинці вважають своє діяння незначним.

Під час опитування пересічних громадян було встановлено, що найефективнішими загальносоціальними заходами, що можуть бути спрямовані на запобігання злочинам у сфері незаконного обігу наркотичних засобів, психотропних речовин, їх аналогів і прекурсорів на території великих міст України, є такі: 1) підвищення рівня правової освіти населення та правового виховання молоді шляхом запровадження сучасних форм і методів профілактики, розроблення інформаційно-пропагандистських та культурновиховних програм, спецкурсів, підготовки і видання підручників з питань запобігання злочинам у сфері незаконного обігу наркотичних засобів, психотропних речовин, їх аналогів і прекурсорів - $55 \%$; 2) удосконалення нормативно-правової бази з питань запобігання злочинам у сфері незаконного обігу наркотичних засобів, психотропних речовин, іх аналогів і прекурсорів - $45 \%$; 3) підвищення рівня фахової підготовки посадових осіб, уповноважених здійснювати запобігання злочинам у сфері незаконного обігу наркотичних засобів, психотропних речовин, їх аналогів і прекурсорів (проведення відповідних семінарів, курсів підвищення кваліфікації, тощо) - 35\%; 4) забезпечення своєчасного виявлення неблагополучних сімей, їх облік і систематична перевірка умов утримання та виховання в них неповнолітніх, надання таким сім'ям адресної допомоги - 47 \%; 5) здійснення заходів щодо забезпечення зайнятості підлітків, юнаків та дівчат, які не мають постійних доходів і джерел для існування, збереження наявної мережі державних і громадських інститутів надання соціальної підтримки неповнолітнім, організації їхнього дозвілля і відпочинку, а також утворення 3 цією метою центрів соціальної служби для молоді, бюро і центрів надання учням та студентам послуг у працевлаштуванні для роботи у вільний від навчання час і під час канікул - 57 \%; 6) запобігання негативним проявам серед неповнолітніх, у тому числі пияцтву, наркоманії, дитячій бездоглядності й безпритульності, забезпечення виявлення дітей, які жебракують, вчиняють правопорушення або стали жертвами злочинної діяльності дорослих - 68 \%; 7) сприяння створенню необхідних умов для проживання та виховання дітей у сім'ї, які б виключали несприятливе побутове оточення, негативний вплив антигромадських елементів, забезпечували притягнення до відповідальності батьків за неналежне виховання, навчання та розвиток дитини $-47 \%$; 8) ужиття заходів 
щодо підвищення ефективності діяльності служб у справах неповнолітніх та кримінальної міліції у справах неповнолітніх - $52 \%$.

Важливою $є$ участь підрозділів ОВС у загальносоціальних заходах, що є складником системи ідеологічної та виховної роботи, яку спільно з громадськістю та ОВС здійснюють державні органи.

Отже, здійснений аналіз матеріалу щодо проблем протидії злочинам, що вчиняються організованими групами та злочинними організаціями, які сформовані на етнічній основі, створить певні напрацювання для подолання цього явища у світовому масштабі суб'єктами, які здійснюють заходи щодо запобігання та протидії злочинам, що буде запорукою плідної міжнародної співпраці щодо запобігання організованій етнічній злочинності загалом [15, с. 1003-1004]. Реалізація загальносоціальних заходів запобігання злочинності взагалі створює необхідні підстави для застосування спеціально-кримінологічних заходів запобігання злочинам у сфері незаконного обігу наркотичних засобів, психотропних речовин, їх аналогів і прекурсорів у великому місті.

Також, як зазначає С.О. Павленко, суспільство, яке виховане в середовищі 3 низькими моральними принципами, не зможе ефективно протистояти [16, с. 88] злочинності загалом.

\section{Висновки}

Підводячи підсумок, слід зауважити, що реалізація перерахованих вище профілактичних заходів сприятиме забезпеченню громадського порядку в місцях скупчення молоді, запобігатиме вживанню наркотичних засобів, пияцтву та іншим негативним чинникам, що зумовлюють антигромадський паразитичний спосіб життя, i, відповідно, будуть опосередковано сприяти запобіганню злочинності [17, с. 159]. Тому нині пріоритетними напрямами запобігання злочинам у сфері незаконного обігу наркотичних засобів, психотропних речовин, їх аналогів i прекурсорів у великому місті для України є: профілактика такої злочинності за участі всіх зацікавлених органів державної влади, місцевого самоврядування й громадських організацій; удосконалення законодавчого регулювання та нормативної бази; розроблення наукового підгрунтя й упровадження новітніх технологій у сфері запобігання корисливим насильницьким злочинам, що вчиняють етнічні організовані злочинні групи; ефективне використання можливостей міжнародного співробітництва [18]. I на завершення слід зазначити, що протидія наркозлочинності потребує особливої уваги та особливих підходів як вчених, які розробляють методичні рекомендації, так і практичних працівників, які іх використовують під час виявлення, припинення, профілактики та запобігання [19, с. 80].

\section{Список використаних джерел:}

1. Михайлов В. О., Білошкурський О.В.Протидія наркобізнесу в Україні: кримінологічний та криміналістичний аспект. Dictum factum. 2019. № 1. С. 121-126.

2. Монтескье Ш. О духе законов. Хрестоматия по истории государства и права зарубежных стран. Москва, 1982. 356 с.

3. Долгова А. И. Криминология. Москва : Изд. группа НОРМА-ИНФРА, 1999. 272 с.

4. Саламатова М.В. Кримінологічна характеристика та запобігання злочинам у сфері нотаріальної діяльності : дис. ... канд. наук з юр. наук: 12.00.08. Запоріжжя, 2015. 249 с

5. Кримінологія : Загальна та особлива частини : підруч. для студ. юрид. спеш. виш. навч. закладів / І. М. Даньшин, В. В. Голіна, О. Г. Кальман, О. В. Лисоєд ; за ред. проф. І. М. Даньшина. Харків : Право, 2003.

6. Кисельов М.О. Кримінологічна характеристика та запобігання підрозділами карного розшуку вчиненню злочинів у великому місті (на прикладі м. Дніпропетровська) : дис. ... канд. юрид. наук: 12.00.08. Дніпропетровськ, 2010. 249 с.

7. Павленко С.О. Причини та умови службових злочинів у сфері охорони довкілля. Кримінологічна теорія $і$ практика: досвід, проблеми съогодення та шляхи їх вирішення : тези доп. наук.-практ. конф. (м. Київ, 26 берез. 2015 року) / ред. кол. В.В. Чернєй, О.М. Джужа, В.В. Василевич та ін. Київ : Нац. акад. внутр. справ, 2015. C. $235-238$.

8. Зависимость между уровнем безработицей и системой уголовного наказания в США. Борьба c преступностью за рубежом (по материалам зарубежной печати): ежемес. информ. бюлл. 1993. № 4. С. $60-61$.

9. Антонян Ю.М. Социальная среда и формирование личности преступника (неблагоприятные влияния на личность в микросреде) : учебное пособие. Москва: Акад. МВД СССР, 1975. 159 с.

10. Про державну допомогу сім'ям із дітьми : Закон України від 21.11.1992 № 2811-ХІІ (в ред. від 22.03 .01 р.). Відомості Верховної Ради України. 2001. № 20. Ст. 102

11. Про додаткові заходи щодо запобігання дитячій бездоглядності : Указ Президента України від 28.01.2000 № 113/2000. Праия $і$ зарплата. 2000. № 6 .

12. Про заходи щодо розвитку духовності, захисту моралі та формування здорового способу життя громадян : Указ Президента України від 27.04.1999 р. № 456/99. URL: https:// zakon.rada.gov.ua/laws/show/456/99\#Text (дата звернення: 12.01.2021).

13. Про обіг в Україні наркотичних засобів, психотропних речовин, іх аналогів і прекурсорів 
Закон України від 08.07.1999 № 863-XIV. Відомості Верховної Ради Украӥни. 1999. № 36. Ст. 317.

14. Грохольський В.Л. Деякі аспекти протидії наркобізнесу на сучасному етапі в України. Матеріали Всеукраїнської науково-практичної конферениї «Боротьба з наркобізнесом: проблеми та шляхи їх вирішення». Одеса: НДРВВ ОЮГ НУВС 2002. C. $6-9$.

15. Севрук В.Г. Правоохоронні органи, які здійснюють протидію злочинам, що вчиняються організованими групами і злочинними організаціями, які сформовані на етнічній основі: український та міжнародний досвід. Молодий вчений. 2017. № 11 (51). С. 995-1005.

16. Павленко С.О. Духовність і моральний контроль як умова запобігання та протидії корупції. Юридична психологія в Україні: здобутки та перспективи : тези доп. наук.-практ.конф. Т. 2 (м. Київ, 26 берез. 2015 року) / ред. кол. В.В. Чернєй, М.В. Костицький, О.I. Кудерміна та ін. Київ : Нац. акад. внутр. справ, 2015. С. 86-89.

17. Дьордяй В. I. Кримінологічна характеристика та запобігання органами внутрішніх справ згвалтувань, що вчиняються неповнолітніми : дис. ... канд. юрид. наук : 12.00.08. Київ, 2015. $233 \mathrm{c}$.

18. Севрук В.Г., Павленко С.О. Заходи протидії транснаціональному наркобізнесу, що вчиняється представниками окремих етнічних груп. Юридичний часопис Начіональної академії внутрішніх справ. 2015. № 2. С. 193-205.

19. Sevruk, V. Definition and classification of the ethnic crime in Ukraine. European Reforms Bulletin: scientific peer-reviewed journal, 1, p. 64-68.

Andrii Krotiuk. General social measures to prevent crimes in the field of illicit trafficking in narcotic drugs, psychotropic substances, their analogues and precursors in the big city

The problem of crime prevention in the field of drug trafficking. psychotropic substances, their analogues and precursors in the big city must be addressed in the context of combating crime in general. A prerequisite for success in the implementation of general social measures to prevent crimes in the field of drug trafficking. psychotropic substances, their analogues and precursors, in particular and all crime in general, is to achieve a qualitatively different state of our society, in which a person must have a strong life status. To do this, it is necessary to make significant changes in the most important spheres of public life, taking into account the interests of all segments of society. To prevent crimes in the field of drug trafficking. psychotropic substances, their analogues and precursors must implement a set of socio-economic, political, organizational and managerial, educational, technical, legal and other measures. Prevention of crimes committed by units of the National Park of Ukraine in large cities is a complex, multifaceted process that has certain signs of integrity. Therefore, it is advisable to consider it comprehensively, highlighting the constituent elements. General social prevention of crimes in the field of drug trafficking is determined by the three most important components that give rise to this type of antisocial behavior - economic, social and moral. Based on this, there are three areas in which it is necessary to carry out preventive work at the social level: economic, social and moral and psychological. Accordingly, the article analyzes and proposes general social measures to prevent crimes in the field of illicit trafficking in narcotic drugs, psychotropic substances, their analogues and precursors in a large city.

Key words: prevention, general social measures, organized criminal groups, drugs, drugs, big city. 